\title{
A nemzetközi és hazai nöi torna, valamint a rokon sportágak helyzetképe a Rió de Janeiró-i Olimpiai Játékok tükrében
}

\section{Survey of international and Hungarian gymnastics and related sports based on the Rio Olympic Games}

\author{
Kalmár Zsuzsanna, Gyulai Gergely, Adorjánné Olajos Andrea, Katus \\ Tamás, Hamar Pál
}

Testnevelési Egyetem (TF) Torna, RG, Tánc és Aerobik Tanszék

\begin{abstract}
Absztrakt - A tornaversenyek népszerúsége töretlen, amit a legutóbbi Olimpiai játékok nézettségi mutatói is húen tükröznek (www.olympic.org). A népszerúség azonban nem csak a „klasszikus” nói és férfi tornaversenyekre igaz, hanem a másik két olimpiai szakágra, a ritmikus gimnasztikára és a gumiasztal-ugrásra is. Ha ehhez a négy szakághoz még hozzávesszük a három, nem olimpiai részt vevő, szintén a torna „holdudvarába” tartozó sportágat, az aerobikot, az akrobatikus tornát és a mindenki tornáját, kirajzolódik a FIG (Fédération Internationale de Gymnastique) hét, világviszonylatban harmadik-negyedik legmarkánsabb sportági rendszere. A nói torna a kecsesség, az esztétikum és a nóiesség megtestesítője - tartották elődeink. Véleményünk szerint ez az állítás a 21. században is helytálló, de már egészen más dimenzióban. Az elmúlt 15 évben nem csak Nyugat-Európában, hanem Dél-Amerika országaiban is látványos fejlódésen ment keresztül a torna. Néhány éve már olyan országok is elénk kerültek, amelyekkel az 1980-as, '90-es években nem találkoztunk világversenyeken, vagy nem számítottak potenciális ellenfélnek. llyenek például Puerto-Rico vagy Brazlia. Egy sportoló felkészítése, sportpályafutásának irányítása igen összetett feladat, ahol a tudomány nem közvetlenül, hanem közvetve, de állandóan jelen van a mindennapi edzói munkában. Szükséges egy hosszú kiválasztási folyamat, rendszeres kondicionálás, technikai és taktikai képzés, illetve pedagógiai és pszichikai felkészítés. Tanulmányunkban a szabályok vizsgálatával (amelyek talán rátelepednek az edzókre és versenyzókre), illetve a Riói Olimpiai Játékok elemzésével próbálunk választ kapni arra, hogy hol helyezkedünk el mi magyarok a nói tornában és rokon sportágaiban a világszínvonalhoz képest.
\end{abstract}

Kulcsszavak: FIG, esztétika, szabályok, világszínvonal

\begin{abstract}
The popularity of gymnastics competitions is unbroken, which is well-reflected in the rating indices of the latest Olympic Games (www.olympic.org). This popularity is true not only for the 'classical' men's and women's artistic gymnastics competitions, but also for the two new branches (rhythmic gymnastics, trampolining) as well. If we add the three additional sports belonging to the sphere of gymnastics, but not forming part of the Olympic Games (aerobics, acrobatics and Gymnastics for All), these seven sports of the FIG (Fédération Internationale de Gymnastique) form the third or fourth most prominent sports-system of the world. Women's gymnastics is the manifestation of gracefulness, aesthetics and womanhood - as was said by our ancestors. According to the authors, this statement is true in the 21st century as well, but in a completely different dimension. Gymnastics has undergone a spectacular development not only in Western Europe, but in South American countries as well. Such countries have left Hungary behind that could not be met either in the 1980s or in the 1990s, or they did not prove to be potential opponents for the Hungarians. These countries include, for example, Puerto Rico and Brazil. The preparation of an athlete and the managing of his/her sports career is a complex task, where science is also at present; not directly, but permanently. A long selection process,
\end{abstract}


regular conditioning, technical and tactical training and pedagogical-psychological preparation are required. In the paper, the authors are willing to analyse the rules (which might weight heavily on both the trainers and competitors) and the Rio Olympic Games to get an answer as to where Hungary is (positioned) in women gymnastics and in related gymnastics events compared to the world elite level.

Keywords: FIG, aesthetics, rules and regulations, elite level

\section{Bevezetés}

A tornaversenyek népszerűsége töretlen, amit a legutóbbi Olimpiai Játékok nézettségi mutatói is hűen tükröznek (www.olympic.org). A népszerüség azonban nem csak a „klasszikus” női és férfi tornaversenyekre igaz, hanem a másik két olimpiai szakágra, a ritmikus gimnasztikára és a gumiasztalugrásra is. Ha ehhez a négy szakághoz még hozzávesszük a három, nem olimpiai résztvevő, szintén a torna „holdudvarába” tartozó sportágat, az aerobikot, az akrobatikus tornát és a mindenki tornáját, kirajzolódik a FIG (Fédération Internationale de Gymnastique) hét, világviszonylatban harmadiknegyedik legmarkánsabb sportági rendszere.

Kerezsi Endre (1971) a torna mozgásrendszerét, gyakorlatanyagát négy nagy csoportra osztotta. Ezek a rendgyakorlatok, az előkészítő gyakorlatok (gimnasztika), a fö gyakorlatok (sporttorna) és a testnevelési játékok tornafeladattal. Ehhez a négy csoporthoz vette még hozzá - akkori szakkifejezéssel élve - a modern gimnasztikát (művészi tornát).

A tornasport köznapian két jelzővel illethető; egyrészt alapsportág, másrészt olimpiai sportág. A tornáról mindent egybevetve azt mondhatjuk ,hogy olyan testgyakorlatok összessége, amely saját mozgásrendszerből áll, ahol térben, időben és sajátos erőkifejtésekkel oldanak meg feladatokat. Ezek a feladatok nagyon sokfélék, megjelenési módjuk rendkívül változatos, hiszen történhetnek talajon, szereken, levegőben, támaszban, függésben, ugrások közben egyaránt (Hamar, 2011).

A torna terminus technikust bővebben értelmezve megállapítható, hogy az magában foglalja a talaj- és a szertorna-gyakorlatok teljes tárházát, a gimnasztika és a ritmikus gimnasztika (szabad-, társas és kéziszer gyakorlatok) mozgásanyagát, a verseny és fitnesz aerobik elemeit, elemkapcsolatait, gyakorlatait, valamint az akrobatikus torna és a gumiasztal-ugrás komplex tevékenységkörét. A teljesség igénye nélkül, csak példaként felsorolva tehát ebbe a sportági körbe tartozik a reggeli tornától kezdve, a ma oly' divatos step-aerobikon és kondi tornán át a felemáskorlát-gyakorlatoktól a gúlaépítésig minden mozgásforma. Mozgásanyagát tekintve idesorolhatjuk akár az akrobatikus rock and roll táncot is (Hamar, 1997).

A torna gyakorlatanyaga a feladatok megoldási lehetőségének változatosságát a tevékenység egészével való összefüggésében tükrözi. Más szóval ez annyit jelent, hogy nem az egyes gyakorlatelemekben, hanem azok együttesében nyilvánul meg a cselekvési szabály. A felkészültség mértékét ezért nem egy-egy gyakorlat reprezentálja, hanem a többféleség birtoklása. A felkészültség mértékét mutatja az is, milyen nehéz feladat megoldására képes a tornász. A tornára jellemző lényeges jegy még, hogy egy-egy feladat megoldásához olyan forma választható, amiből a következő gyakorlatelem folyamatosan végrehajtható (kombinációk, gyakorlatok) (Leopold, 1992).

$\mathrm{Ha}$ a torna helyét keressük a sportágak rendszerében, számos megközelítés létezik. Az egyik megközelítés szerint (Dubecz, 2009) a gyakorlások során feltárulkozó közös taktikai tevékenységjellemzők alapján csoportosíthatunk. Ezen az alapon a torna a sorsolásos sportágak - zártmozgású készségek, egyéni versenyzők (torna, műkorcsolya, műugrás stb.) - közé sorolható. A csoport versenyzési keretei meghatározzák a stratégiai-taktikai döntések lehetőségeit. A versenyzők önálló gyakorlataikat egymástól időben, térben függetlenül mutatják be, így közvetlenül nem hathatnak egymás teljesítményére. A taktikai cselekvés sportszerü lehetősége itt szűk keretek között mozog.

Tulajdonképpen ezzel cseng egybe Istvánfi Csa$b a$ (1981) felosztása is, ahol a kiindulópont a mozgáskészségek zárt és nyílt jellegét megkülönböztető elmélet. Itt a differenciálás alapja a mozgáskészségek alkalmazásának környezeti körülményei és 
szabályozásának fó jellege. A mozgáskészségeknek azt a fajtáját nevezzük zárt jellegűnek, amelyeknek elsajátítása és alkalmazása közben a belső szabályozó folyamatoké (propriocepció) a vezető szerep, és amelyek a versenykörülmények között jelentős mértékben nem módosulnak, sőt a versenyző akkor lesz igazán eredményes, ha képes a jól elsajátított mozgást (technikát, végrehajtási módot) versenykörülmények között reprodukálni. A zárt készségek végrehajtási formája a tanulási, gyakorlási, valamint az alkalmazási, versenyzési körülmények között lényegében azonos. A zárt készségek zárt jellegét az adja, hogy az alkalmazásukat nem befolyásolják lényegesen a környezetből jövő információk. Egyes esetekben a külső körülmények ugyan befolyásolhatják a készségeket, de azokat a képzett sportoló elöre látja. Az ilyen jellegű sportágaknál a cél bizonyos számú szokás, sztereotípia kiépítése az előre látható körülményekhez.

Emellett képezhetünk sportági csoportokat a sportági profil edzésmódszertani szempontokat követő megrajzolásával is. A felosztás alapját ekkor az a minősítés jelenti, amely a teljesítmény szempontjából meghatározó tulajdonságok, jellegek szerint tesz különbséget. Ennek értelmében kialakíthatunk képesség-dominanciájú, technika-dominanciájú és taktika-dominanciájú csoportokat. Nyomatékosan hangsúlyozandó viszont, hogy a csoportosítás nem jelent valamiféle kizárólagosságot, hiszen minden sportágban megtalálhatóak a képesség-, technikai és taktikai jellegü összetevők. A különbség leginkább az arányokban lelhető fel, azaz például a „technika-dominanciájú” csoportot a technikai végrehajtás színvonalának túlsúlyáról ismerjük fel, miközben a „képességek”, a kondicionális képességek és a "taktika” jelenlétét is érzékeljük. A technika-dominanciájú sportágcsoportba tartozik a torna, a ritmikus gimnasztika, az akrobatikus torna, a gumiasztalugrás és az aerobik is (Rigler, 2004).

A női torna a kecsesség, az esztétikum és a nőiesség megtestesítője - tartották elődeink. Véleményünk szerint ez az állítás a 21. században is helytálló, de már egészen más dimenzióban ( $H a-$ mar és Kalmár, 2005). Az elmúlt 15 évben nem csak Nyugat-Európában, hanem Dél-Amerika országaiban is látványos fejlődésen ment keresztül a torna. Sajnos már olyan országok is elénk kerültek, amelyekkel az 1980-as, '90-es években nem találkoztunk világversenyeken, vagy nem számítottak potenciális ellenfélnek. Ilyenek például Puerto Rico vagy Brazília. Egy sportoló felkészítése, sportpályafutásának irányítása igen összetett feladat, ahol a tudomány nem közvetlenül, hanem közvetve, de állandóan jelen van a mindennapi edzői munkában. Szükséges egy hosszú kiválasztási folyamat, rendszeres kondicionálás, technikai és taktikai képzés, illetve pedagógiai és pszichikai felkészítés is (Kalmár,2015). Tanulmányunkban a szabályok vizsgálatával (amelyek talán rátelepednek az edzőkre és versenyzőkre), illetve a Riói Olimpiai Játékok elemzésével próbálunk választ kapni arra, hogy hol helyezkedünk el mi magyarok a női tornában és rokon sportágaiban a világszínvonalhoz képest.

\section{Anyag és módszer}

Az adatok bemutatásánál azon statisztikai elemzésekre támaszkodtunk, melyet az Olimpiai Játékok után a Nemzetközi Torna Szövetség (FIG) Technikai Bizottsága készített (www.fig-gymnastic. com; www.fig-gymnastics.com/rules/code).

A Riói Olimpián résztvevő női tornászok létszáma 98 fö volt 50 különböző országból. Ez a létszám, az utolsó kvalifikációs világverseny (Glasgow-i VB) 1-12. helyezett csapataiból (öt versenyző) és 38 ország egy fös egyéni versenyzőiből tevődött össze. Bár a kvalifikációs rendszer többlépcsős, a legutolsó, a Glasgow-i volt a mindent eldöntő. Ha kontinensekre bontjuk a résztvevőket, a következő százalékos adatokat kapjuk:

1. táblázat. A Riói Olimpia női tornaversenyén részt vevő sportolók kontinensek szerinti eloszlása (\%)

\begin{tabular}{|c|c|c|}
\hline Kontinensek & Országok & $\mathbf{\%}$ \\
\hline Európa & 25 & 50,00 \\
\hline Amerika & 14 & 28,00 \\
\hline Ázsia & 7 & 14,00 \\
\hline Óceánia & 2 & 4,00 \\
\hline Teljes & 50 & $\mathbf{1 0 0}$ \\
\hline
\end{tabular}


A teljes létszámú csapattal résztvevő 12 ország a következő volt: BEL, BRA, CAN, CHN, FRA, GBR, GER, ITA, JPN, NED, RUS, USA. A 38 egyéni versenyző az alábbi országokból került ki: ALG, ARG, ARM, AUS, AUT, BLR, CHI, COL, CRO, CUB, EGY, ESP, GRE, GUA, HUN, IND, IRL, ISL, JAM, KOR, MEX, NZL, PAN, PER, POL, POR, PRK, ROU, SLO, SUI, SVK, SWE, TTO, TUR, UKR, UZB, VEN, VIE. A felsorolásból kitűnik, hogy a Riói Olimpián az országunkat a női mezőnyben egy versenyző képviselte, mégpedig Kovács Zsófia (Dunaferr SE).

Az olimpiai versenyszámok több napon keresztül zajlottak mind a női, mind pedig a férfi versenyzőknél. A selejtezők - ahol lényegében az összes versenyző elindult (98/82) - az előbbiekben bemutatott 50 ország tornászainak részvételével folytak.

$\mathrm{Az}$ egyéni összetett versenybe (24 versenyzö, maximum 2 fó országonként) 10 országból (BRA, CAN, CHN, FRA, GER, ITA, JPN, NED, RUS, USA) 2-2 versenyző, míg 4 országból 1-1 versenyző (BEL, GBR, SUI, VEN) került be. Összesen 14 különböző ország tornászaitól láthattunk gyakorlatokat.
A csapatdöntő résztvevői (a nyolc legjobb csapat a selejtező eredménye alapján) a következő országok voltak: USA, RUS, CHN, JPN, GBR, GER, NED, BRA.

A szerenkénti döntőkben (maximum két versenyző egy országból) 17 különböző országból versenyeztek női tornászok, azaz: CHN, USA, CAN, RUS, SUI, BRA, FRA, GBR, GER, IND, ITA, JPN, NED, PRK, ROU, UZB, VEN.

\section{Eredmények}

\section{Érmes helyezések}

A fenti felsorolásokból jól látható, hogy menynyire széles skálán mozog a mezőny. Nagyon sok országból, sok kiváló adottságú tornásznő szerepelt az Olimpián. Kiegyenlítődött a világ tornája, így már régen nem beszélhetünk orosz vagy román hegemóniáról.

A következő táblázatban az érmes helyezések eloszlása látható. Hét nemzet tornászai között oszlottak meg a dobogós helyezések. Az érmes helyezések kontinensek szerinti eloszlása a 3. táblázatban látható.

2. táblázat. A nemzetek érmes helyezéseinek eloszlása a Riói női tornaversenyen

\begin{tabular}{|c|c|c|c|c|}
\hline Nemzetek & Arany & Ezüst & Bronz & Összesen \\
\hline USA & 4 & 4 & 1 & 9 \\
\hline RUS & 1 & 2 & 1 & 4 \\
\hline NED & 1 & & & 1 \\
\hline CHN & & & 1 & 1 \\
\hline GER & & & 1 & 1 \\
\hline GBR & & & 1 & 1 \\
\hline SUI & & & 1 & 1 \\
\hline Összesen & 6 & 6 & 6 & 18 \\
\hline
\end{tabular}

3. táblázat. Az érmes helyezések kontinensek szerinti eloszlása a Riói női tornaversenyen

\begin{tabular}{|c|c|c|c|c|}
\hline Kontinensek & Arany & Ezüst & Bronz & Összesen \\
\hline Amerika & 4 & 4 & 1 & 9 \\
\hline Európa & 2 & 2 & 4 & 8 \\
\hline Ázsia/Óceánia & & & 1 & 1 \\
\hline
\end{tabular}




\section{A tornásznök életkori eloszlása}

Érdekes statisztikai adat még a tornászlányok életkorbeli eloszlása is. A 4. táblázat azt szemlélteti, hogy a legidősebb tornász 41 éves volt (egy fö), míg a legfiatalabbak 16 évesek voltak (tíz fó). A nemzetközi szabály szerint 16 évesek lehetnek a legalacsonyabb életkorú tornásznők, akik elindulhatnak felnőtt versenyeken.

4. táblázat. A születési évek eloszlása a Riói Olimpia női tornaversenyén

\begin{tabular}{|c|c|c|}
\hline Születési év & Tornásznö (fö) & $\%$ \\
\hline 1975 & 1 & 1,02 \\
\hline 1984 & 2 & 2,04 \\
\hline 1986 & 1 & 1,02 \\
\hline 1987 & 1 & 1,02 \\
\hline 1989 & 4 & 4,08 \\
\hline 1990 & 2 & 2,04 \\
\hline 1991 & 8 & 8,16 \\
\hline 1992 & 4 & 4,08 \\
\hline 1993 & 4 & 4,08 \\
\hline 1994 & 7 & 7,14 \\
\hline 1995 & 7 & 7,14 \\
\hline 1996 & 8 & 8,16 \\
\hline 1997 & 10 & 10,20 \\
\hline 1998 & 12 & 12,24 \\
\hline 1999 & 17 & 17,35 \\
\hline 2000 & 10 & 10,20 \\
\hline
\end{tabular}

Az 5. táblázat azt mutatja meg, hogy az elmúlt nyolc év világversenyein milyen volt az átlagéletkor eloszlás. Pekingben a 19. életévhez közeli volt az átlag, míg Londonban már több mint 20 év. A
Riói statisztika mutatja a legmagasabb értéket, ami majdnem 21 év. A 6. táblázatban a Riói Olimpiai Játékokon szerepelt csapatok átlagéletkorát tüntettük fel.

5. táblázat. Három olimpiai ciklus átlagéletkor eloszlása a tornásznőknél

\begin{tabular}{|c|c|c|}
\hline Verseny & Tornásznő (fö) & A versenyeken részt vett tornásznők átlagéletkora \\
\hline 2016 OG & 98 & 20,693 \\
\hline 2015 WC & 261 & 19,17 \\
\hline 2014 WC & 250 & 19,34 \\
\hline 2013 WC & 134 & 19,16 \\
\hline 2012 OG & 97 & 20,124 \\
\hline 2011 WC & 216 & 18,72 \\
\hline
\end{tabular}




\begin{tabular}{|c|c|c|}
\hline $2010 \mathrm{WC}$ & 217 & 18,20 \\
\hline $2009 \mathrm{WC}$ & 146 & 18,03 \\
\hline $2008 \mathrm{OG}$ & 98 & 18,66 \\
\hline
\end{tabular}

OG =Olimpiai Játékok, WC = Világbajnokság

6. táblázat. A női tornászcsapatok átlagéletkora a Riói Olimpián

\begin{tabular}{|c|c|}
\hline Nemzet & Életkor (év) \\
\hline BEL & 18,60 \\
\hline BRA & 21,80 \\
\hline CAN & 18,80 \\
\hline CHN & 18,20 \\
\hline FRA & 17,80 \\
\hline GBR & 19,40 \\
\hline GER & 20,80 \\
\hline ITA & 20,80 \\
\hline JPN & 18,60 \\
\hline NED & 22,60 \\
\hline RUS & 18,80 \\
\hline USA & 19,40 \\
\hline
\end{tabular}

A legfiatalabb csapat: 17,80 év (FRA), a legidösebb csapat: 22,60 év (NED), a csapatok átlagéletkora: 19,633év.

Az adatokból az látszik, hogy az átlagéletkor 20 év vagy legalább is ahhoz közeli, így már nem beszélhetünk „kislányok” tornájáról. Az is nyilvánvaló, hogy a 30 vagy az a fölötti korosztályban tornázó versenyzők nem dominánsak, de mindenképpen figyelmet érdemel, hogy jóval több idősebb tornásznő van a porondon, mint néhány évvel korábban. A miértre a válasz mindenekelőtt a szerfejlődés és az edzők szakmai felkészültsége lehet. Ezen felül magyarázat lehet még egy-egy kivételes képességü, alkati adottságú tornász, mint például Oksana Chusovitina (41 éves), aki gyermekszülés után, 35 éves tornászmúlttal a háta mögött még mindig képes egy-egy szeren a magas színvonalat tartani. Ez a teljesítmény minden szempontból kivételes, ilyen nem volt és azt gondoljuk, a közeljövőben nem is lesz. Viszont az, hogy az átlagéletkor kitolódott és elegáns, kiforrott tornásznőkben gyönyörködhetünk, ez mindenképpen üdvözlendő.

\section{Kiemelkedö gyakorlatok és pontszámok}

Egy másik elemzésünk a gyakorlatok értékelésére, szabályok által történő pontozásának vizsgálatára terjed ki. Ennek keretében bemutatunk néhány kimagasló pontszámot és azt, hogyan-miből tevődik össze egy-egy gyakorlat értéke a szabályok alkalmazásával.

A legmagasabb pontszám a selejtező 
versenynapon 16,100 volt, amit az USA versenyzője Simone Biles ért el ugráson. Az egyéni összetett napon a legmagasabb pontszám 15,933 volt, amit szintén Simone Biles kapott talajon. A csapatdöntő napján a legmagasabb pontszámot $(15,933)$ két tornásznő érte el, ugráson Simone Biles, és felemáskorláton az orosz Mustafina Aliya. A szerenkénti döntő legmagasabb pontszáma 15,966 volt, ami szintén Simone Biles nevéhez füződik talajon.

A versenyeken a pontszámok egy-egy szeren több pontozó, illetve két „panel” által jönnek létre. A gyakorlatok nehézségi értékét a „D”, azaz a difficulties zsűri értékeli. A gyakorlatok általános, szer-speciális technikai hibáit az „E”, azaz execution zsűri vonja le. A „D” panel a versenyzőknek pontot ad: a legértékesebb nyolc elemet értékeli, valamint az elemcsoport követelményeket $(5 \mathrm{x} 0,50=2,50)$, amennyiben azt teljesíti a versenyző. Emellett a magas értékkel bíró elemek különleges kapcsolataiért ad még plusz tizedeket. $\mathrm{Az}$ „E” panel viszont a 10,00 pontból az előbbiekben felsorolt hibákért levonásokat alkalmaz. Így a két különböző pontszám összeadása után jön létre például a 15,966os pontszám. A két „D” bíró egy pontszámot ad, míg öt „E” bíró - ahol a legalacsonyabb és a legmagasabb pontszám kiesik, így a megmaradt három pontszám átlaga adja az „E” pontszámot - és két referensbíró értékeli a gyakorlatokat. A referensbírók („E”) pontszámai csak abban az esetben számítanak, amennyiben nagy az eltérés az öt „E”, technikai pontszámot adó bíró pontjai között.

Egy-egy szer mellett tehát kilenc pontozóbíró dolgozik. Rajtuk kívül még időmérők és vonalbírók is követik a gyakorlatokat. Amennyiben az időmérők és a vonalbírók pontszámeltérései a szabályokat meghaladják, mint semleges hibák, ezek is levonásra kerülnek a végpontszámból. A bíróknak úgynevezett szimbólírással kell a gyakorlatokat visszakövethetően leírniuk. Minden elemnek (akrobatikusnak és gimnasztikusnak egyaránt), saját rajza van, amit a bírónak az alkalmazás szintjén, kívülről kell tudnia. Ezek az elemek ABC szerint kerültek besorolásra, eszerint kell számolni velük. Az elemek, a nehézségi foktól függően, az „A” értéktől az „I” értékig lettek besorolva, az „A” elem 0,1, míg az „” elem 0,9 tized pontot ér.

A világversenyek programját általában új elemek is tarkítják. Ezeket az elöször sikeresen bemutató tornászról nevezik el, de csak abban az esetben, ha azt tényleg nem csinálta még korábban senki. A Riói Olimpián két olyan női újdonságot láthattunk, amik - sikeres bemutatás után -, elfogadott elemként bekerültek a nemzetközi kódba (Code of Point). Ezek az újítások mindenesetben a tornasport fejlődését mutatják. Bővítik a repertoárt, így a tornászok és az edzők az elemtanulási folyamat során többféle elemből tudnak válogatni. Ez azért (is) fontos, mert a gyakorlatokba csak azokat az elemeket lehet betenni, amelyek a nemzetközi kódban szerepelnek.

A Riói Olimpiai Játékok női tornaversenyén az alábbi két újítást láthattuk (2. és 3. ábra). A 2. ábrán az az új, gerendára történő felugrás látható, amit Marisa Dick Trinidad és Tobagói tornásznő mutatott be az Olimpián. Az elem értéke „D”, vagyis 0,4 tized.

A 3. ábrán egy felemáskorlátra történő felugrást mutat be a tornásznő, aki Rióban Houry Gebeshian (Örményország) volt. Ennek az elemnek az értéke is „D”, vagyis 0,4 tized.

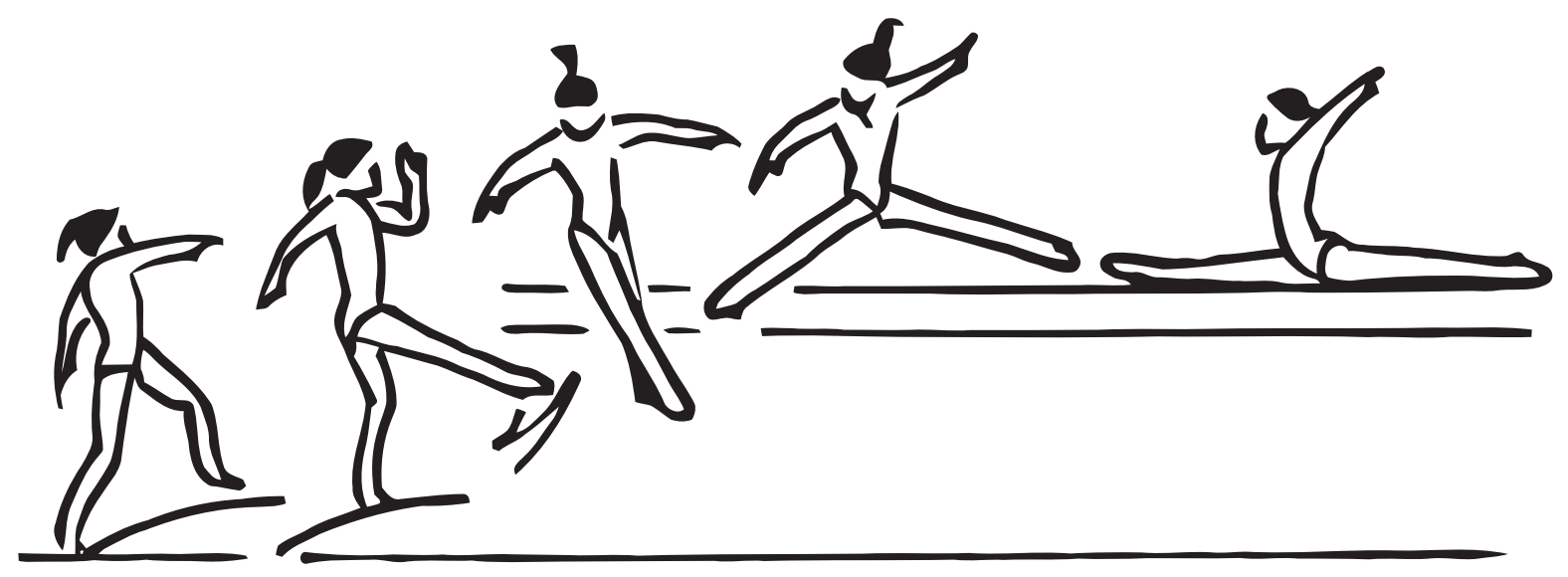

2. ábra. Váltó futóátugrás, $180^{\circ}$-os fordulattal a levegőben, érkezés haránt spárgába kézletétel nélkül a gerendára (www.fig-gymnastics.com/rules/code) 


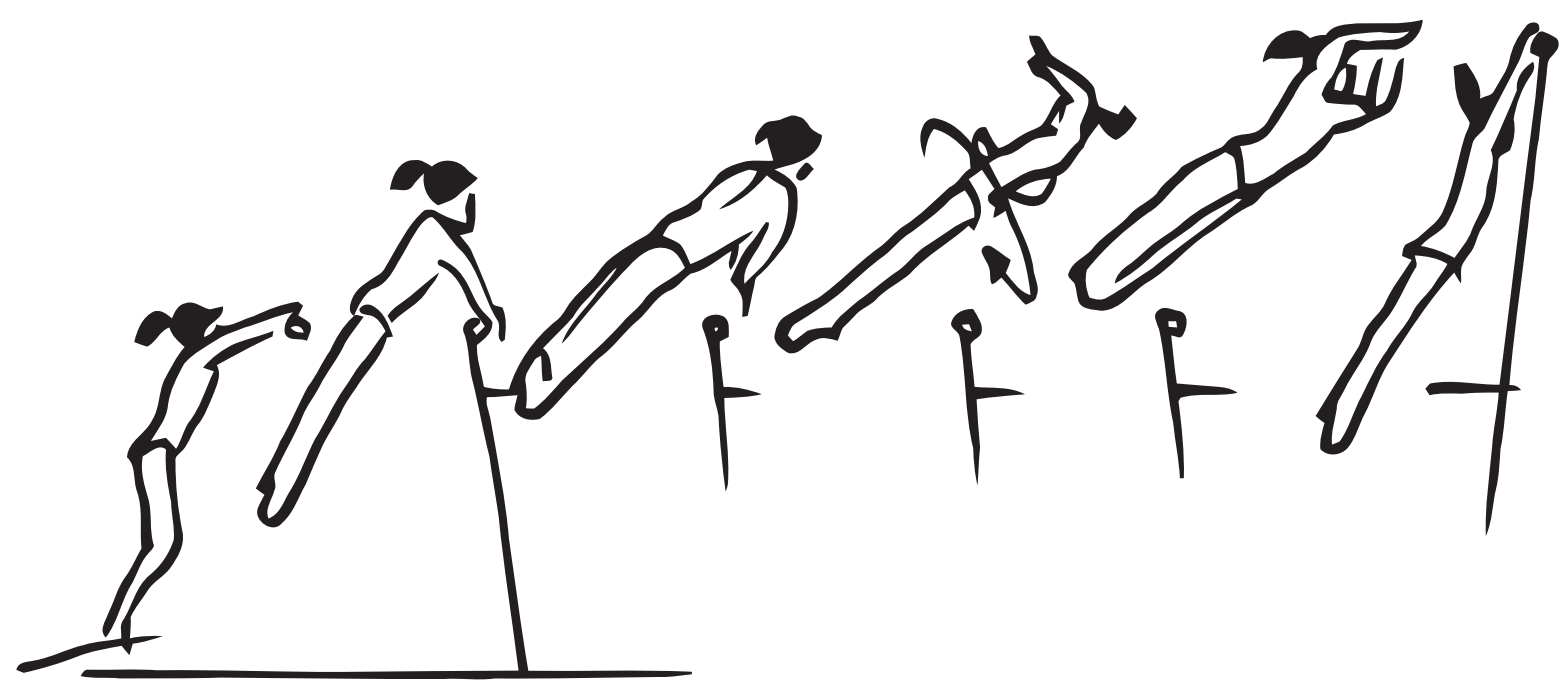

3. ábra. Felemáskorláton „hect” felugrás $360^{\circ}$-os fordulattal a magas karfára (www.fig-gymnastics.com/ rules/code)

\section{A magyar női torna helyzete a sportágban - ösz- szegző gondolatok}

Azzal együtt, hogy sem a női sem pedig a férfi tornászválogatott csapat szinten nem volt jelen a Riói Olimpián, így ezen a téren nem túl elökelö helyet foglalunk el a sportágban, azt kell, hogy mondjuk, hosszú, nehéz, s eredménytelen évek után talán felfelé kezd elmozdulni sportágunk. Ezt mi sem bizonyítja jobban, mint, hogy idén tavaszszal az Európa Bajnokságon a magyar női csapat a legjobb nyolc közé került. Ez azt jelenti, hogy a legközelebbi klasszikus rendezésü EB-n az utolsó csoportban versenyezhetünk, vagyis, ahol a legjobb nyolc csapat méri össze a tudását. Válogatottunk oszlopos tagjai - akiket eleganciájuk miatt nagyon szeretnek a bírók - a nemzetközi szinten is értékes gyakorlatokkal rendelkeznek. Az utánpótlás korosztályban is egyre több olyan tornásszal bővült sportágunk, akikkel a jövőben remélhetőleg sok szép eredménnyel gazdagodhatunk. A cél adott: újból csapat szinten képviselje magát Magyarország az Olimpiákon a női és a férfi tornában egyaránt.

A női tornasportról adott rövid elemzés nem ad(hat) választ arra, hogy miért van lemaradásunk a nemzetközi mezőnyben, inkább újabb kérdéseket vet fel. A korai szakosodás, a túl fiatalon történő sportágkezdés nem lehet megoldás, mert még alacsonyabb életévekben kezdeni illuzórikus lenne. A mennyiségi munka növelése sem kiút, tekintettel a gyermekek teherbíró képességére. Az edzésfeltételek - bár javításra mindig szükség van - számos helyen biztosítottak. Úgy gondoljuk, hogy az edzők részéről egyfajta minőségi foglalkozásra lenne szükség. Az oktatás során az edzők jelenleg túlnyomó részben a mozgások tanításával és begyakoroltatásával foglalkoznak, míg a tudatos szabályozás, az önkontroll, az önszabályozás kialakítása a tornászoknál kisebb szerepet kap. Nagyobb hangsúlyt kellene fektetni egy sor - föként pszichológiai - tényező működtetésére és fejlesztésére, amelyek a technikai végrehajtás mellett a gyakorlatok ,jóságáért" is felelősek. Ezek a mozgást szabályozó tényezők még nagyrészt hiányoznak a felkészítésből. A motoros fejlesztésbe tehát újabb szempontokat érdemes bekapcsolni, amiktől az eredményesség javulását várhatjuk (Kalmár, 2014).

A pszichológia egyik fontos kérdése, hogy mimilyen késztetésből fakad és milyen erők állnak az emberi viselkedés hátterében. Miért tudunk bizonyos cselekvésekre hatalmas energiákat mozgósítani, míg másokra nem. A sport világában a legtöbbet használt szavak közé tartozik a motiváció, amely meghatározza a szervezet aktivitásának mértékét, a viselkedés szervezettségét és hatékonyságát. Ez a sokoldalú befolyásolás belső személyiségvonásokat és külső hatásokat vagy következményeket fejez ki, amelyek a motivált viselkedést szabályozzák. A torna sportban speciális jelentőséggel bír a motiváció, ami nélkül lehetetlen egy sportoló életében elérni és megtartani a kitűzött célt, célokat. Rókusfalvy Pál (1980) tágabb értelmezésében azt írja, hogy „a motiváción az emberi tevékenységnek $-s$ így a sporttevékenységnek is - a társadalmi környezettől 
is meghatározott késztetését, ösztönző szabályozását értjük.”

Az edzői célok egyike minden sportágban - esetünkben, a tornasportban -, hogy miképpen tudjuk a leghatékonyabban motiválni tanítványainkat a versenyeken és a felkészítés folyamatában, azaz az edzéseken. A fizikai (testi) és pszichikai teljesítmények viszonyát egy komputer hasonlattal érdemes megvilágítani. Ebből a szempontból a tornász teste, fizikuma lenne a hardware, a pszichikai működés pedig a software. A tornász a testével mutatja be gyakorlatát, ezt látjuk és értékeljük (a gyakorlaterősség és a kivitelezés szintjén). A gyakorlatok azonban a háttérben álló pszichológiai szabályozó tényezőktől függenek, a testi végrehajtást minden részletében irányítják. Még az automatizmusokat is, hiszen ezeket hosszú tanulási folyamat előzte meg. A tornagyakorlatok elemzésénél tehát a pszichológiai háttér (a software) tanulmányozására is szükség van (Kalmár, 2014).

\section{A ritmikus gimnasztika ( $R G$ ) és az aerobik sportágak rövid értékelése}

\section{Ritmikus gimnasztika ( $R G)$}

Másik olimpiai sportágunkban, az RG-ben ezen az Olimpián sajnos nem szerepelt egyetlen magyar versenyző sem. A kvalifikációs világversenyeken nem sikerült megszerezni az olimpiai részvételi kvótát. A következőkben ennek a problémának az okait keressük RG szakemberek néhány gondolatának tolmácsolásával.

1956 Melbourne - A szertorna részeként megjelenő hétfős művészi torna együttes kéziszer csapat szalaggal olimpiai bajnok lett. A csapat tagjai: Keleti Âgnes, Bodó Andrea, Kertész Alíz, Tass Olga, Köteles Erzsébet, Korondi Margit és a tartalék Nagy Márta. Óriási fejlődési, átalakulási folyamaton ment keresztül a mozgásanyag, míg a mai nevén ritmikus gimnasztika - immár önálló sportágként egyéni és együttes kéziszer versenyszámokban is - szerepelt 2016-ban Rióban.

A mélyreható változások 2000-ben kezdődtek, aminek fö törekvése az objektív mérhetőség volt. Ekkor kerültek leírásra a különböző nehézségi fokú ugrás, forgás, egyensúly- és hajlékonysági elemek. A fö mérőszámok: a csípőízületi hajlékonyságot mutató $180^{\circ}$-os lábnyitások, valamint a forgások mérőszámaként megjelenő minimum $360^{\circ}$-os fordulatok. Ennek eredményeként a gyakorlatok koreográfiái elsősorban a minél magasabb értékü elemek halmazát jelentették, melyeket „aláfestésként" zene is kísért.

A nemzetközi bírói testület minden olimpia után összeül és kiértékeli az elmúlt négy évben tapasztalható változásokat a sportág arculatát illetően. Ezeknek az üléseknek és szakmai elemzéseknek az eredményeként Rióban igazán nőies, harmonikus és esztétikus sportági mozgásanyagot láthattunk, bravúros szertechnikai tudással vegyítve. Hosszú idő után ismét előtérbe került a zene és a mozgás összhangjának megjelenítése, melyet gyönyörü, tiszta test- és szertechnika kísért. Az együttes kéziszer gyakorlatokban is fellelhetö volt ugyanez a törekvés. A régmúlttal történő összevetésben feltűnő változás a csapat összetételének száma, mely napjainkra öt före szűkült.

Összességében megállapítható, hogy a folyamatosan változást indukáló szabályok eredményeként az RG napjainkra megfelelő arányt talált a müvészeti és a sport jellege között.

Nagyon tiszta és magas szintű technikai tudás mellett magas fokú művészeti ággá fejlődött. A sportág eredményes nemzeteiben továbbra sincs mélyreható változás, azaz a vezető országok: Oroszország, Ukrajna, Fehéroroszország, Bulgária, Izrael, Olaszország, Franciaország, Grúzia és Spanyolország. Célunk a közeljövőben az előbbiekben felsorolt 9 ország mögé kerülni és újból olimpiai kvótát szerezni. Ezért a célért, edzőink folyamatos jelenléttel bővítik szakmai tudásukat hazai illetve nemzetközi edzőképzéseken. Mindezek mellet sportdiplomáciai vonalunk erősítése is kiemelt szerepet kap sportágunk szövetségében.

\section{Aerobik}

A másik, szintén a torna „holdudvarába” tartozó sportág, ami még nem szerepel az olimpiai sportágak között, az Aerobik. Ez a sportág néhány gondolatot azért is megérdemel, mert óriási fejlődésen ment keresztül, ha csak az utóbbi hat-nyolc évet vesszük figyelembe.

A fejlődés ellenére eddig nem sikerült az olimpiai sportágak közé beverekednie magát.

A 2013-2016-ig tartó olimpiai ciklust egy korábbi mérföldkő alapozta meg. Az aerobiknak 2011-ben meghívott sportágként lehetősége volt szerepelni a versenyprogramban az Universiadén, a kínai Shenzenben. Ekkor vegyes páros, trió, csoport, aerostep, aerodance kategóriákban rendeztek versenyt. A magyar felsőoktatásban tanuló 
versenyzőkből összeállitott egységek itt még nem jutottak ugyan döntőbe, de részvételüket kivívva, sporttörténelmet írtak. Ez volt ugyanis az első olyan világesemény, ahol olimpiai sportágakkal együtt szerepeltek a sportág versenyzői.

A 2013-as Világjátékok Caliban már tradicionálisnak számított, hiszen az aerobik 1997 óta része a világjátékoknak. Kolumbiában hatalmas érdeklödés övezte a versenyt, példaként említenénk, hogy 18.000 néző volt jelen a döntőn. A vegyes páros, csoport, aerostep, aerodance kategóriákban zajló versenyen a magyar válogatott tagjai aerostepben és aerodanceben a 4., míg csoport kategóriában az 5. helyezést szerezték meg. A 2014-es Gymnasiadéra, Brazíliába szintén első alkalommal volt meghívva az aerobik sportág középiskolás korosztálya. Itt kimagasló magyar eredmények születtek, négy kategóriában arany-, illetve egy kategóriában ezüstérmet szereztek versenyzőink. A bakui Európai Játékok 2015-ben újabb újdonságot hozott. Amellett, hogy maga az esemény is először került megrendezésre, a FIG olimpiai és nem olimpiai szakágai együtt képviseltették magukat egy nagy érdeklődéssel kísért sporteseményen. Szakmai siker, hogy a vegyes páros és a csoport kategóriában zajló versenyen magyar aranyérem született.

A magyar aerobikosoknak az Európa-bajnokságok is sorra sikert jelentettek ebben az olimpiai ciklusban. A 2013-ban Franciaországban, Arquesban és a 2015-ben Portugáliában, Elvasban megrendezett kontinens viadalokon, az utánpótlás korábbi sikereire alapozva, már felnőtt válogatottunk is kiválóan szerepelt. A hétből hat kategóriában is dobogós helyezéseket szereztünk. Bár a kategóriákban megszerezhető arany még várat magára, a nemzetek közötti versenyben felnőttjeink holtversenyben Romániával mégis feljutottak „Európa csúcsára”.

A világbajnokságok 1998 óta tartó történetében 2014-ben a mexikói Cancunban először kerültünk dobogóra és dobogó közelébe. Ezt a 2016-os koreai Incheonban megrendezett világbajnokságon sikerült „megfejelni”, ugyanis a nemzetek versenyében a felnőttek között 4 . helyet szereztünk. A kategóriákban két ezüstérem mellett, több döntős helyezést is sikerült elérni, ami sikeres kvalifikációt jelentett a 2017-es lengyelországi Világjátékokra. A 2016-os törökországi Trabzonban megrendezett Gymnasiadén csak egy magyar középiskolás korú versenyző indult, női egyéniben, aki a döntőben 6 . helyezést ért el.
Sportágunk korszerủ szabálymódosításai, mozgásanyag fejlődése és a versenyek látványossága, remélhetőleg elégséges lesz ahhoz, hogy 8-12 éven belül lehetőség nyíljon a nyári Olimpiai Játékokon való szerepeléshez.

\section{Hivatkozásjegyzék}

1. Dubecz József (2009): Általános edzéselmélet és módszertan. Önkormányzati Minisztérium Sport Szakállamtitkárság. Rectus Kft., Budapest. 214-219.

2. Hamar Pál (1997): Testedzés és torna a 8 és 15 éves leányok heti időrendjében. Kalokagathia, 1-2. sz. 49-57.

3. Hamar Pál (2011): Az iskolai tornaoktatás elmélete és módszertana. Semmelweis Egyetem Testnevelési és Sporttudományi Kar (TF), Budapest.12-13.

4. Hamar Pál, Kalmár Zsuzsa (2005): A magyar női torna helyzete a 2004. évi Amszterdami Európa Bajnokság eredményeinek tükrében. Magyar Edzo, 1. sz. 14-17.

5. Istvánfi Csaba (1981): Stratégia és taktika. In: Nádori László: Az edzés elmélete és módszertana. Sport, Budapest. 203-247.

6. Kalmár Zsuzsa (2014): Az utánpótlás és felnőtt válogatott tornásznők tornaspecifikus attitűdjei és személyiség jellemzői hazai, illetve nemzetközi összehasonlításban. Doktori értekezés. Testnevelési Egyetem, Budapest. 4-7.

7. Kalmár Zsuzsa (2015): Merre tart a női torna? Magyar Edző, 2. sz. 32-34.

8. Kerezsi Endre (1971): Sporttorna. Sport, Budapest. 5-10., 13-65.

9. Leopold József (1992): A torna, mint egyetemi diszciplína. A Magyar Testnevelési Egyetem közleményei, 1. sz. 87-111.

10. Rigler Endre (2005): Az általános edzéselmélet és módszertan alapjai. III. rész A felkészítés: a kondicionális képességek felkészítése. Szakmailag lektorálta: Dr. Nádori L., Budapest.13-17.

11. Rókusfalvy Pál (1980): A testedzés és a sporttevékenység ösztönzése: a motiváció és a motiválás pszichológiai kérdései. Testnevelés- és Sporttudomány, 2. sz. 9-14.

12. www.olympic.org

13. www.fig-gymnastic.com

14. www.fig-gymnastics.com/rules/code 